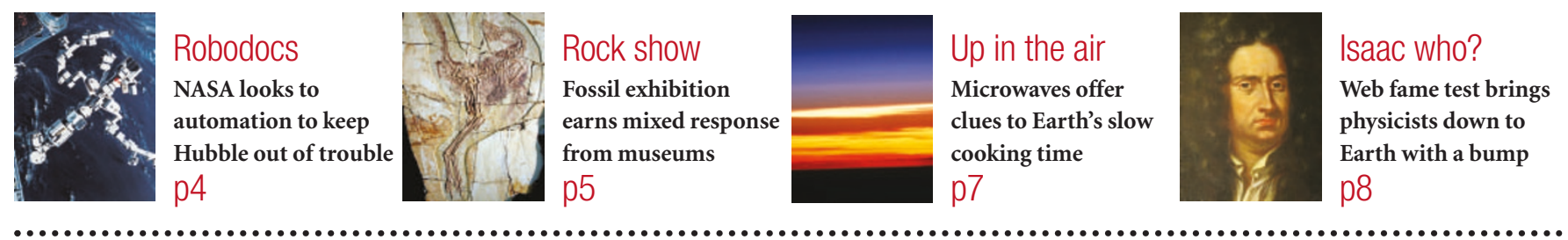

\title{
Korea's stem-cell stars dogged by suspicion of ethical breach
}

\section{David Cyranoski, Seoul}

When, in February, a South Korean team announced that it had derived stem cells from a cloned human embryo, its achievement was heralded as an important step on the road to 'therapeutic cloning'. But the research is now clouded by nagging questions about the source of the key resource for the experiment: human egg cells.

Korean citizens'-rights activists and bioethicists are pressing the team, led by Woo Suk Hwang and Shin Yong Moon of Seoul National University, to prove that the recruitment of women volunteers followed ethical guidelines. Nature's enquiries have also revealed troubling inconsistencies — in particular over whether the donors included junior members of the research team.

The brewing controversy could undermine the domestic public and political support on which Hwang and Moon's progress has depended (see News Feature, page 12). Any suggestion of ethical irregularities in therapeutic-cloning research could also have international repercussions, providing ammunition for activists who are opposed to the technology on moral grounds.

Therapeutic cloning involves creating an embryo by transferring the nucleus from a patient's cell into a human egg cell stripped of its own nucleus. After being grown in culture for a few days, this clone can yield embryonic stem cells, which can develop into any of the body's tissues. Because these would be derived from the patient's own cells, there should be no problem with immune rejection in using grafts derived from them to repair diseased or damaged tissues.

But cloning is very inefficient. To derive a single line of embryonic stem cells, the Korean team used 242 eggs obtained from 16 volunteers (W. S. Hwang et al. Science 303, 1669-1674; 2004). Each woman was given hormone injections to force her ovaries to superovulate, producing 12-20 eggs per menstrual cycle instead of one.

Other researchers were surprised that so many women were prepared to undergo this procedure for a research project. Side effects of the treatment can range from general discomfort and emotional stress to clotting of

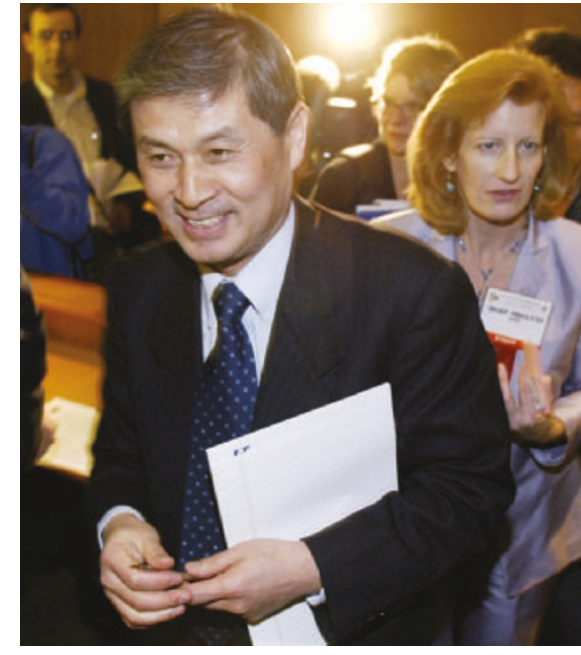

Woo Suk Hwang faces increasing scrutiny over how he recruited egg donors for his research.

the veins or stroke. "It's a painful procedure and there is risk involved," says Jose Cibelli, a co-author on the paper who studies cloning at Michigan State University in East Lansing. "It would never fly in the United States."

Hwang says that the donors were motivated by a desire to push forward a promising field of medicine. "Many women are sympathetic with our research," he says. Supplementary material published online with the paper says that the volunteers were not paid, and explains that they filled in informed-consent forms detailing how the eggs would be used.

\section{Egg donations}

The donors were anonymous, but one $\mathrm{PhD}$ student in the team, Ja Min Koo, initially told Nature that the donors included herself and another woman in the lab. She subsequently called back and said that she had not donated eggs, blaming her poor English for a misunderstanding. But in the initial interview, she named the hospital where her donation was carried out, and explained that she had been happy to donate eggs because she already has two children.

Art Caplan, who heads the Center for Bioethics at the University of Pennsylvania in Philadelphia, argues that it would be bad practice if egg donors for such a project included students or junior employees on the research team because "it could certainly look like coercion was involved".

The information posted with the paper also states: "Neither donors nor their family, relatives or associates may benefit from this research." Koo, who was a co-author on the paper, arguably did stand to gain professionally from its publication.

Hwang denies that Koo was among the donors. But he declined Nature's requests for further documentary evidence of the procedures for recruiting the egg donors and obtaining their consent. Attempts to get more information from the Institutional Review Board at Hanyang University Hospital in Seoul, which provided ethical approval, were similarly rebuffed. Its chair, university obstetrician Moon-il Park, cancelled an arranged phone interview.

Within Korea, concern is growing about the lack of transparency surrounding the procedures for obtaining the donated eggs. "I'm doubtful women would give their eggs so easily," wrote Pil Pyul Lee, a science historian at the Korea National Open University in Seoul, in the 23 February issue of the Professors Times, a nationwide newspaper in which academics express their views on topical issues.

Lee's article also questioned the inclusion as a co-author on the paper of KyYoung Park, a plant molecular biologist formerly at Sunchon National University who is now a science and technology adviser to South Korean President Roh Moo-hyun. Park says that she has played an important role in Hwang's research over the years by advising him on public attitudes to his work with transgenic livestock, but she told Nature that she had no specific involvement with the therapeutic-cloning paper.

One of South Korea's leading citizens'rights groups, People's Solidarity for Participatory Democracy, now says that it will look into the ethical issues surrounding the cloning paper. "We plan to pressure the government to force them to produce the documents that are required," says Jae-kak Han, who heads the group's scientific division. The Korean Bioethics Association is also pressuring the National Human Rights Commission to look into the matter. 